\title{
Effects of cholinergic compounds and TNF-alpha on human erythroleukemia K562 cell proliferation and caspase expression
}

\author{
Kolinerjik bileşiklerin ve TNF-alfanın insan eritrolösemi K562 hücre çoğalmasına ve kaspaz \\ ekspresyonu üzerine etkileri
}

Zehra KANLI, Banu AYDIN, Hulya CABADAK

\begin{abstract}
Objective: The purpose of this study was to investigate if stimulating auto-paracrine muscarinic receptor signalling pathway could change human erythroleukemia K562 cell proliferation and caspase 3, 8 and 9 expression levels. To better understand the role of muscarinic receptors in cell signalling mechanism, we investigated the effects of several compounds on human erythroleukemia K562 cell proliferation and caspase 3, 8 and 9 expression. These compounds were $\mathrm{M}_{3}$ muscarinic receptor agonist, pilocarpine, proinflammatory cytokine, tumor necrosis factor (TNF)-alpha, and the wortmannin which is a phosphoinositide 3-kinase inhibitor.

Materials and Methods: Cell proliferation and cell viability were evaluated by the trypan blue exclusion test and 5-Bromo-2deoxy-uridine (BrdU) Labelling and Detection Kits. Caspase 3, 8 and 9 expression levels were determined by immunoblot analysis.

Results: Both pilocarpine and TNF-alpha caused a small increase in human erythroleukemia K562 cell proliferation. However, when all the compounds were treated together, proliferation of human erythroleukemia K562 cells increased significantly when compared to untreated control cells. TNF-alpha and wortmannin treatment increased caspase 3 and caspase 8 expression patterns significantly in human erythroleukemia K562 cells. TNF-alpha and wortmannin treatment increased caspase 9 expression level $(\mathrm{P}>0.05)$ but it was not significant.

Conclusion: These findings partly demonstrated that $M_{3}$ muscarinic receptor mediated an increase in K562 cell proliferation. Pilocarpine prevented TNF-alpha and wortmannin induced caspase 3 and 8 expression and indirectly showed apoptosis in human erythroleukemia K562 cells.
\end{abstract}

Keywords: $\mathrm{M}_{3}$ muscarinic receptors, Cytokine, Pilocarpine, Caspases, Erythroleukemia K562 cells

Zehra Kanli, Banu Aydin, Hulya Cabadak (两)

Department of Biophysics, School of Medicine, Marmara University, Maltepe, Istanbul, Turkey

e-mail:hcabadak@gmail.com

This study was presented in the $4^{\text {th }}$ International Congress of The Molecular Biology Association of Turkey MolBiyoKon, November 27 29, 2015, Middle East Technical University, Ankara, Turkey.
ÖZ

Amaç: $\mathrm{Bu}$ çalışmanın amacı, otoparakrin $\mathrm{M}_{3}$ muskarinik reseptör sinyal yolağının uyarılmasının, insan eritrolösemi K562 hücrelerinin çoğalmasında ve kaspaz 3, 8 ve 9 ekspresyon seviyeleri üzerinde etkisi olup olmadığını araştırmaktır. Hücre sinyal ileti mekanizmasında muskarinik reseptörlerin rolünü daha iyi anlamak üzere, çeşitli bileşiklerin insan eritrolösemisi K562 hücre proliferasyonu ve kaspaz 3, 8 ve 9 ekspresyon seviyeleri üzerindeki etkilerini araştırdık. Bu bileşikler, $\mathrm{M}_{3}$ muskarinik reseptör agonisti, pilokarpin, pro-enflamatuvar sitokin, tümör nekroz faktör (TNF)alfa ve fosfoinositid 3-kinaz inhibitörü wortmanindir.

Gereçler ve Yöntemler: Hücre çoğalması ve hücre canlılığg1, tripan mavisi testi ve 5-Bromo-2-deoxy-uridine (BrdU) İşaretleme ve Belirleme kitleri ile değerlendirildi. Kaspaz 3, 8 ve 9 ekspresyon seviyeleri immunoblot analizi ile belirlendi.

Bulgular: Hem pilokarpin, hem de TNF-alfa, insan eritrolösemi K562 hücre çoğalmasında çok az artışa neden oldu. Ancak, tüm bileşikler birlikte muamele edildiğinde, insan eritrolösemi K562 hücrelerinin çoğalması, muamele edilmeyen kontrol hücrelerine göre anlamlı olarak arttı. TNF-alfa ve wortmanin ile muamele edilen K562 hücrelerinde kaspaz 3 ve kaspaz 8 ekspresyonu seviyelerinde anlamlı değişim belirlendi. TNF-alfa ve wortmannin muamelesi kaspaz 9 ekspresyon seviyesini arttırdı $(\mathrm{P}>0.05)$ ancak anlamlı değildi.

Sonuç: Bu bulgular, kısmen $\mathrm{M}_{3}$ muskarinik reseptör aracılı K562 hücre çoğalmasında artış olduğunu göstermektedir. Pilokarpin, insan eritrolösemi K562 hücrelerinde, TNF-alfa ve wortmanin ile uyarılan kaspaz 3 ve 8 ekspresyonunu önledi ve dolaylı olarak apoptozu gösterdi.

Anahtar kelimeler: $\mathrm{M}_{3}$ muskarinik reseptorler, Sitokin, Pilokarpin, Kaspaz, Eritrolösemi K562 hücreleri

\section{Introduction}

Chronic myelogenous leukemia (CML) which accounts for $20 \%$ of leukemia cases (annually $1-1.5 / 100.000$ within a wide range of age width), is a malignant, clonal hematopoietic stem cell disorder [1]. Human erythroleukemia K562 cells derived from a 53-year-old female patient with CML in blast 
crisis behaved as pluripotent hematopoietic stem cells. Thus, they can serve as a model system to study hematopoietic cell growth and differentiation [2]. Muscarinic receptors are G protein coupled receptors (GPCR). The $\mathrm{M}_{1}, \mathrm{M}_{3}$ and $\mathrm{M}_{5}$ muscarinic receptor subtypes (mAChRs) are coupled to $\mathrm{G} \alpha_{\mathrm{q}}$ that activates phospholipase C (PLC) enzyme which breaks down phosphatidylinositol 4, 5-bisphosphate (PI) into diacylglycerol (DAG) and inositol triphosphate ( $\left.\mathrm{IP}_{3}\right)$. The $\mathrm{M}_{2}$ and $\mathrm{M}_{4}$ mAChRs are coupled to $\mathrm{G} \alpha_{i} / \mathrm{G} \alpha_{0}$ and inhibit adenylate cyclase leading to a decrease in the formation of intracellular cyclic adenosine monophosphate (cAMP) [3-5]. Different cancer types are expressed by $M_{3}$ muscarinic receptor subtype (mAChR). The $\mathrm{M}_{3} \mathrm{mAChR}$ induces more than one signalling pathway in different types of cancer cells. Muscarinic receptor signalling pathways are related to cellular growth, survival, inflammation, angiogenesis, invasion, migration, pro-survival and anti-apoptosis in cancer cells. The stimulation of $M_{3}$ muscarinic receptors has been linked to the phosphoinositide three kinase (PI3K)/Akt pathway, which plays a role in the growth and proliferation of astrocytoma cells [6]. Muscarinic receptors are relatively abundant in the central nervous system and peripheral parasympathetic nervous system [3]. Muscarinic receptors also mediate some cellular events in hematopoietic cells and other non-neuronal cell types [4]. Recent experiments showed that non-neuronal cells and tissues express a mixture of muscarinic receptor transcripts. Muscarinic receptor subtypes have different functions [5]. In our previous studies we showed that $M_{2}, M_{3}$ and $M_{4}$ subtypes of $m A C h R$ were expressed in human erythroleukemia K562 cell line and muscarinic activation led to erythroleukemia cell proliferation dependent on the presence of fetal bovine serum (FBS) [79]. The treatment of serum-deprived human erythroleukemia K562 cells with carbachol (CCh), a cholinergic agonist, led to a significant increase in DNA synthesis. $\mathrm{CCh}$, also could produce a decrease in the DNA synthesis in human erythroleukemia K562 cells supplemented with $1 \%$ or $10 \%$ FBS after starvation [9]. The results of our previous studies also showed that nitric oxide (NO) release increased through $\mathrm{M}_{3}$ receptors in the human erythroleukemia K562 cells [7].

Programmed cell death or apoptosis involves the activation of a series of cysteine aspartyl-specific proteases (caspases) related pathway and cell morphology changes. Caspase activation mechanisms are important in the apoptotic signalling pathway. During apoptosis two apoptotic pathways have been determined. These are cellsurface death receptor-dependent extrinsic pathway that activates caspase 8 and 10 and the other, the mitochondriadependent intrinsic pathway that activates caspase 9. Both extrinsic and intrinsic pathways lead to changes in the caspase 3, 6 and 7 expression levels [10-11].

Tumor necrosis factor (TNF)-alpha has several roles in biological responses like stress response, cell proliferation, differentiation, apoptosis and inflammation [12]. TNFalpha, is produced by the activated macrophages and by different types of cells. TNF-alpha can induce both proand anti-apoptotic signalling pathways. TNF-alpha binds to R1 and R2 subtypes of the TNF receptors. These receptors activate caspase 8 related pathway [13]. Previous studies showed that, TNF-alpha can trigger not only the cell death, but also cell survival pathway as well [14]. Wortmannin negatively regulates the PI3K/Akt pathway.

The aim of the present work was to investigate the role of $\mathrm{M}_{3}$ muscarinic receptor agonist pilocarpine on proliferation and caspase 3, 8 and 9 expression levels in K562 cells in a medium supplemented with 1\% FBS after starvation. K562 cells were stimulated with pilocarpine in the presence or absence of other compounds in a medium supplemented with $1 \%$ FBS after starvation. We further investigated the effects of pro-inflammatory cytokine, TNF-alpha, the PI3kinase inhibitor and wortmannin on cell proliferation in K562 cells. It remains unclear whether muscarinic $M_{3}$ stimulation contributes to the effects produced against the pro-inflammatory cytokines like TNF-alpha and wortmannin.

\section{Material and Methods}

Cell line and antibodies were used in the study. K562 cells were purchased from the American Type Culture Collection (ATCC) (Rockville, MD). 5-Bromo-2-deoxy-uridine (BrdU) Labelling and Detection Kits were supplied from Roche Company (Mannheim, Germany). The antibodies were purchased from Santa Cruz Biotechnology Inc (Santa Cruz, CA, USA). Secondary antibodies were purchased from Sigma (StLouis, MO, USA). Pilocarpine, TNF-alpha and wortmannin were purchased from Sigma-Aldrich Company (St. Louis, MO). Pilocarpine was prepared as $100 \mathrm{mM}$ stock in distilled water, filtered through 0.2 $\mu \mathrm{m}$ filter, and stored at $-80^{\circ} \mathrm{C}$. TNF-alpha was prepared as a $1 \mathrm{ng} / \mathrm{ml}$ solution in dimethyl sulfoxide (DMSO) and wortmannin was prepared as a $1 \mu \mathrm{M}$ solution in DMSO.

\section{Cell proliferation assay}

Cells were seeded into cell culture dishes and cultured in Roswell Park Memorial Institute 1640 (RPMI-1640) medium supplemented with $2 \mathrm{mM}$-L-glutamine, $1 \%$ heat-inactivated 
FBS, $100 \mathrm{U} / \mathrm{mL}$ penicillin, $100 \mathrm{lg} / \mathrm{mL}$ streptomycin at $37^{\circ} \mathrm{C}$ under a humidified condition of $95 \%$ air and $5 \% \mathrm{CO}_{2}$. Cell viability and proliferation were also evaluated by the trypan blue exclusion test and cell counter (TC-20 BioRad, Hercules, CA, USA). Live and dead cells were distinguished by trypan blue exclusion test. The cell proliferation assay was done by using a BrdU kit. BrdU kit protocol was described in our previous study [8]. $100 \mathrm{ml}$ of passaged K562 cells $\left(1 \times 10^{4}\right.$ cells $)$ were seeded into 96 well plates containing RPMI-1640 medium without FBS. After $24 \mathrm{~h}$, these "starved cells" were placed into a medium containing $1 \%$ FBS. The cells were grown in RPMI 1640 medium supplemented with $2 \mathrm{mM} \mathrm{L}$-glutamine, $1 \%$ heatinactivated FBS, $100 \mathrm{U} / \mathrm{mL}$ penicillin, $100 \mathrm{lg} / \mathrm{mL}$ streptomycin, at $37{ }^{\circ} \mathrm{C}$ under a humidified condition of $95 \%$ air and $5 \% \mathrm{CO}_{2}$. One of the following was then added to TNF-alpha $(1 \mathrm{ng} / \mathrm{ml})$, and /or wortmannin $(1 \mathrm{mM})$ and $30 \mathrm{~min}$ later pilocarpine (100 $\mathrm{mM}$ ) was added and left for $24 \mathrm{~h}$. K562 cells cultured in RPMI1640 medium (Sigma, USA) containing $1 \% \mathrm{FBS}$ in $5 \% \mathrm{CO}_{2}$ incubator at $37^{\circ} \mathrm{C}$, constituted the control group.

\section{Preparation of whole-cell lysates and immunoblot analysis}

Cells were collected at $400 \mathrm{~g}$ and washed two times with phosphate buffered saline (PBS). The resulting pellets were resuspended and lyzed with 20 strokes in a hand dounce homogenizer in a buffer containing $20 \mathrm{mM}$ Hepes- $\mathrm{KOH}$, $\mathrm{pH} 8.0,0.1 \mathrm{mM}$, ethylenediamine-tetraacetic acid (EDTA), $0.1 \mathrm{mM}$ phenylmethylsulfonyl fluoride, $10 \mathrm{mg} / \mathrm{mL}$ leupeptin and $2 \mathrm{mg} / \mathrm{mL}$ aprotinin. The protein content of the whole lysates was determined by the method of Lowry et al. [15]. Immunoblot analyses were described in our previous studies with minor modification [9]. $100 \mathrm{mg}$ of protein was used in immunoblots and blots incubated overnight at $4{ }^{\circ} \mathrm{C}$ with antibodies against caspase 3,8,9 and b-actin in separate blots. Caspases 3, 8 and 9 were quantified versus b-actin on the blot. The apparent molecular weights of caspases 3, 8 and 9 were $11 \mathrm{kDa}, 20 \mathrm{kDa}, 46 \mathrm{kDa}$, respectively. The blots were analyzed by densitometry. Total amount of protein in each lane was normalized to the endogenous b-actin control. Densitometric analysis was carried out with the free edition of the Bio-Rad Molecular Analyst Software Program.

\section{Statistical analysis}

All figures show mean (SD) of at least six independent experiments. Statistically significant differences were determined by using the one-way analysis of variance followed by Dunnett's post-tests. All statistical tests were performed with the Prism program (Graphpad Software) and $(\mathrm{P}<0.05)$ was considered significant. Asteriks were used to describe value levels of statistical significance $\left({ }^{*} \mathrm{P}<0.01\right.$; $* * \mathrm{P}<0.003 ; * * * \mathrm{P}<0.003)$.

\section{Results}

Cells were stimulated with $100 \mu \mathrm{M}$ pilocarpine, $1 \mathrm{ng} / \mathrm{ml}$ TNFalpha, $1 \mu \mathrm{M}$ wortmannin for $24 \mathrm{~h}$, and then cell viability and BrdU assay were carried out. The roles of $M_{3}$ muscarinic receptor agonist, pilocarpine, TNF-alpha, cytokine and PI3kinase inhibitor and wortmannin, on proliferation of K562 cells are seen in (Figure 1). As shown in Figure 1, treatment of K562 cells with TNF-alpha in the absence of wortmannin had a minor stimularity effect on BrdU incorporation (Figure 1), while treatment with $(100 \mu \mathrm{M})$, TNF-alpha and wortmannin together had additive stimulatory effect on BrdU incorporation. When TNF-alpha and wortmannin were added in the absence of pilocarpine, the number of BrdU labeled cells increased to $19.59 \pm 2.1 \%$ of the control. TNF-alpha, wortmannin and pilocarpine increased the number of BrdU-labeled cells to $22.30 \pm 2.20 \%$ of the control group. There was no significant difference between the group treated with pilocarpine and the control group in the medium supplemented with $1 \%$ FBS after starvation. The group treated with TNF-alpha + wortmannin on BrdU incorporation also increased cell proliferation but to a lesser degree when compared to the control group ( $\mathrm{P}<$ 0.05). Another group of cells that was treated with TNFalpha + pilocarpine + wortmannin on $\mathrm{BrdU}$ incorparation also increased significantly compared to the control group $(\mathrm{P}<0.05)$. The roles of $\mathrm{M}_{3}$ muscarinic receptor agonist, pilocarpine, TNF-alpha, and PI3-kinase inhibitor, wortmannin on caspase 8, 9 protein expression in K562 cells were shown in figures 2 and 3. Inhibition of PI3K/Akt by wortmannin influenced the expression of caspase 8 overtly (Figure 2A) and caspase 3 (Figure 3). However, inhibition of PI3K had no effect on the expression of caspase 9 (Figure 2B). The increased caspase 3 expression induced by TNF-alpha and wortmannin was significantly attenuated by the addition of pilocarpine (Figure 3). These results suggested that pilocarpine could protect K562 cells from TNF-alpha and wortmannin induced apoptotic signalling pathway. We observed that combination of PI3Kinase inhibitor, wortmannin and TNF-alpha increased expression of caspase 3, which is executioner or effector caspase and caspase 8, which is an initiator caspase (Figure $2 \mathrm{~A}$ and Figure 3). Wortmannin specifically inhibited the phosphatidylinositol 3-kinase pathway,that could be used as a 
promising apoptosis-based therapeutic agent with TNF-alpha in the treatment of leukemia. Flowchart about the mechanism involved in TNF-alpha and wortmannin mediated apoptosis in human erythroleukemia K562 cells was shown in Figure 4.

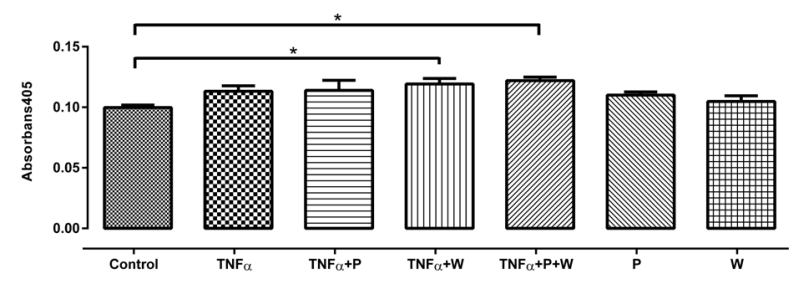

Figure 1. The effects of pilocarpine $(100 \mathrm{mM})$ alone or in the presence of wortmannin $(1 \mu \mathrm{M})$, TNF-alpha $(1 \mathrm{ng} / \mathrm{ml})$ on human erythroleukemia K562 cell proliferation. Cells $\left(1 \times 10^{4}\right.$ cells/well $)$ were disseminated in 96 well dishes in the absence of fetal bovine serum and cultured for $24 \mathrm{~h}$ and then $1 \%$ fetal bovine serum was added with or without pilocarpine, wortmannin and TNF-alpha. The cells were pre-treated with wortmannin 30 min before addition of TNF-alpha. $\mathrm{BrdU}$ was applied for the last $4 \mathrm{~h}$. Each bar represents the mean $\pm \mathrm{SEM}$ of four independent experiments. ${ }^{*} \mathrm{P}<0.05$ between control versus TNF-alpha+wortmannin, TNF-alpha + pilocarpine +wortmannin

$2 A$
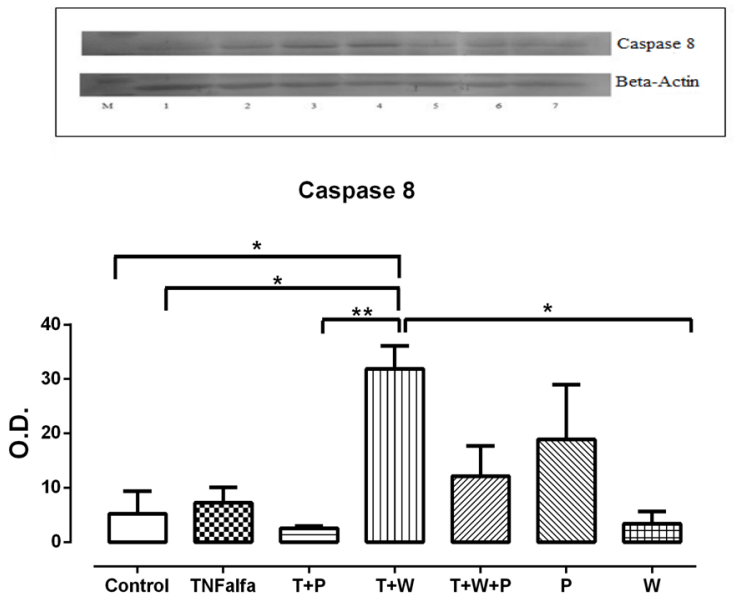

2B

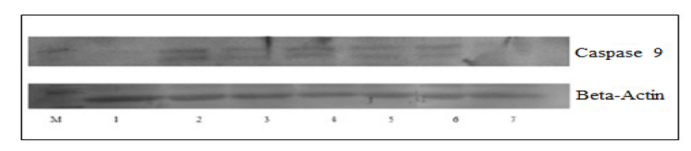

Caspase 9

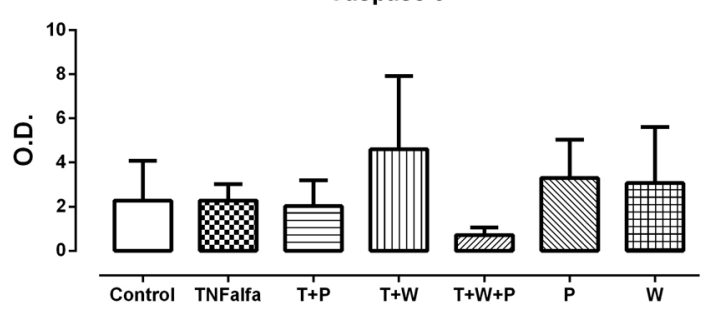

Figure 2. The effect of pilocarpine on the expression of caspase 8 and 9 proteins. K562 cells were treated with wortmannin (1 $\mu \mathrm{M})$ for $30 \mathrm{~min}$ prior to exposure to TNF-alpha $(1 \mathrm{ng} / \mathrm{ml})$ and / or pilocarpine. Western blot analysis for expression of caspase 8 and 9 was performed on whole lysates. (A) Apoptosis initiating protein levels of caspase $8(20 \mathrm{kDa})$ and $(\mathrm{B})$ caspase $9(46 \mathrm{kDa})$ were detected by Western blotting. B-Actin was used to normalize the amount of protein loaded in each lane. Representative Western blot images are shown. Values are expressed as the mean $\pm \mathrm{SEM}$ of four independent experiments. $* \mathrm{P}<0.003$; $* * \mathrm{P}<0.01$.

O.D.: Optical Density, T: TNF-alfa, P: Pilocarpine, W: Wortmannin. 1-Control, 2-TNF-alfa, $3-\mathrm{T}+\mathrm{P}$ (TNF-alfa + pilocarpine), 4-T+W (TNFalfa + wortmannin $), 5-\mathrm{T}+\mathrm{W}+\mathrm{P}((\mathrm{TNF}-\mathrm{alfa}+$ wortmannin + pilocarpine $)$

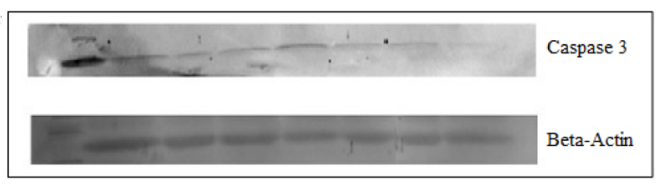

Caspase 3

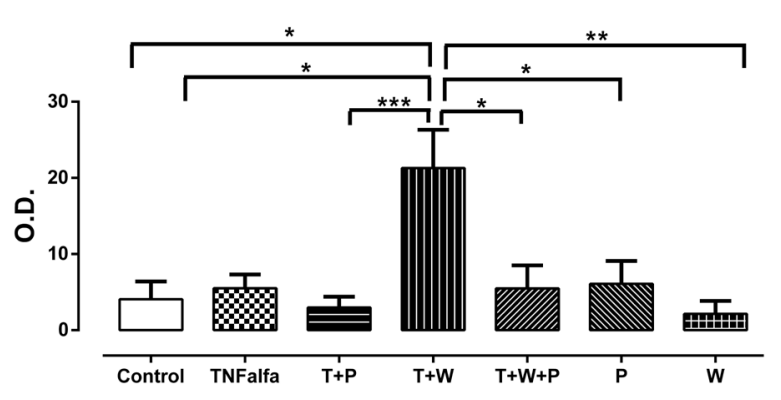

Figure 3. The effect of pilocarpine on the expression of caspase 3 protein. K562 cells were treated with wortmannin $(1 \mu \mathrm{M})$ for 30 min prior to the exposure of TNF-alpha $(1 \mathrm{ng} / \mathrm{ml})$ with or without pilocarpine $(100 \mu \mathrm{M})$. Western blot analyses for expression of caspase 3 were performed on whole lysates. Apoptosis effector protein of caspase $3(11 \mathrm{kDa})$ was detected by Western blotting. B-Actin was used to normalize the amount of protein loaded in each lane. Values are expressed as the mean $\pm \mathrm{SEM}$ of four independent experiments. $* \mathrm{P}<0.003 ; * * \mathrm{P}<0.01 ; * * * \mathrm{P}<0.003$.

O.D.: Optical Density, T: TNF-alfa, P: Pilocarpine, W: Wortmannin. 1-Control, 2-TNF-alfa, $3-\mathrm{T}+\mathrm{P}$ (TNF-alfa + pilocarpine), 4-T+W (TNFalfa + wortmannin $), 5-\mathrm{T}+\mathrm{W}+\mathrm{P}((\mathrm{TNF}-$ alfa + wortmannin + pilocarpine $)$

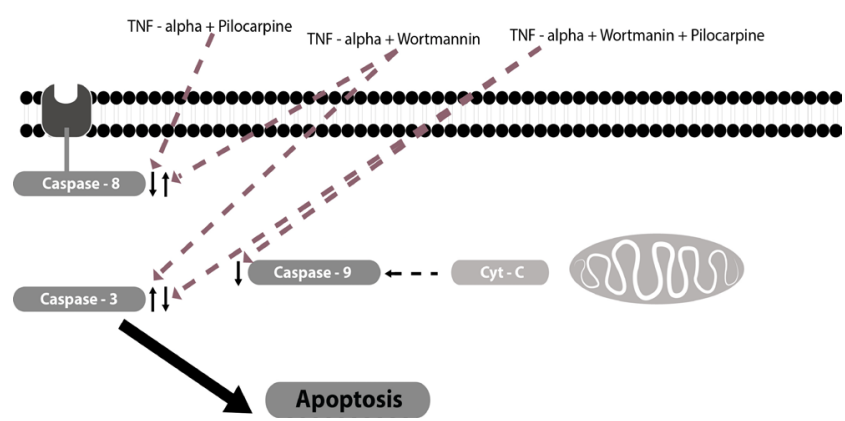

Figure 4. Schematic representation of the mechanism involved in TNF-alpha and wortmannin mediated expression of caspase 3, 8 and 9 during apoptosis of human erythroleukemia K562 cells. 
These findings indicate that pilocarpine may act through $\mathrm{M}_{3} \mathrm{R}$ signalling to prevent apoptosis and promote erythroleukemia cell proliferation, targeting that $\mathrm{M}_{3} \mathrm{R}, \mathrm{PI} 3 \mathrm{~K}$ and TNF-alpha might provide us a potential therapeutic strategy for leukemia treatment.

\section{Discussion}

In the present study, we have demonstrated the effects of TNF-alfa, pilocarpine and wortmannin on the cell proliferation and caspase 3, 8 and 9 expression levels in human erythroleukemia $\mathrm{K} 562$ cells. $\mathrm{M}_{3}$ muscarinic receptor is expressed in different cancer types. These cancer types are the skin, colon, gastric, pancreatic, breast, ovarian, brain and lung [16]. TNF-alpha, produced by activated macrophages, is a cytokine that influences growth, differentiation and apoptosis in most cell types [17]. Different researchers suggested that TNF-alpha could also trigger cell survival pathway that induced NFkB pathway [18]. It was also documented that caspase 3 and 8 may have been the key regulators of the apoptotic response during tumorigenesis [19]. Gonza'lez-Flores and colleagues showed that TNFalfa caused a time dependent increase in caspase 3, 8 and 9 activities in K562 cells [18]. Another group detected similar results in U937 cells [20] but in their study they used different FBS concentration in the cell proliferation medium. Sandra and colleagues showed that a low concentration of TNF-alpha in the presence of wortmannin or LY294002 induced apoptosis in a human head and neck squamous cell carcinoma (SAS) cell line. They suggested that the PI3K-NFkappaB pathway contributed to the TNF-alpha induced cell survival and that inhibition of this pathway accelerated apoptosis in the SAS cell line [21]. Various researchers showed that PI3K/Akt pathway could inhibit cell apoptosis $[22,23]$. PI3K/Akt pathway is also involved in both proliferation and inhibition of apoptosis. It was also demonstrated that the cell proliferation could be evidently inhibited by wortmannin in a dose-dependent manner and wortmannin could arrest the cell cycle and induce cell apoptosis. It was also stated that, a lower concentration of wortmannin did not induce apoptosis [24]. Previously, we had shown that the PI3-kinase inhibitor wortmannin $(1 \mu \mathrm{M})$ had an inhibitory effect on DNA synthesis. But, DNA synthesis was stimulated when wortmannin was added prior to $\mathrm{CCh}$ challenge. We also suggested that different signalling pathways participated in the muscarinic receptor mediated regulation of cell proliferation in one of our previous studies [9]. Exogenous muscarinic agonist, pilocarpine stimulated cell growth in non-small cell lung cancer (NSCLC) A549 and PC9 cell lines but $\mathrm{M}_{2}$ muscarinic antagonist, methoctramine inhibited tumor growth [25]. This study showed that pilocarpine caused a little increase in K562 cell proliferation when compared to the control group, while TNF-alpha and wortmannin had additive effects in increasing K562 cell proliferation in $24 \mathrm{~h}$. TNFalpha, pilocarpine and wortmannin together increased K562 cell proliferation when compared to the control group. The intracellular pathway compounds had biological effects on these cells. Our results led us to conclude that pilocarpine could protect cells from apoptosis. In the present study, when TNF-alpha, PI3K inhibitor and wortmannin were administered together, they induced apoptosis which involved pathways of receptor-mediated apoptosis. But, they did not affect the mitochondrial pathway in K562 cells. As shown, in this study TNF-alpha and wortmannin induced apoptosis via caspase 8 which initiated receptor-mediated apoptosis, but TNF-alpha and wortmannin did not affect caspase 9, mitochondrial cell death pathway in K562 cells, significantly.

Our study suggested that the treatment of human erythroleukemia K562 cells with TNF-alpha and wortmannin induced caspase 3 and 8 expression in the absence of pilocarpine. But, addition of pilocarpine decreased caspase 3 and 8 expression within 24 h in K562 cells. Our results implied an indirect contribution to the apoptotic pathway in human erythroleukemia cells, since we only detected caspase 3, 8 and 9 protein levels. Finally, we provided a flowchart about the mechanisms involved in TNF-alpha and wortmannin mediated apoptotic pathway proteins for the protective effects of pilocarpine in human erythroleukemia K562 cells. $M_{3}$ receptor-mediated suppression of TNFalpha and wortmannin effects may be important protective mechanisms of apoptosis in the erythroleukemia cells.

In conclusion, our results suggested that TNF-alpha and wortmannin together stimulated caspase 3, 8 expression and finally increased apoptosis in human erythroleukemia cells.

Pilocarpine prevented TNF-alpha and wortmannin induced apoptotic protein and expression of caspase 3 and 8 in K562 cells, resulting in the inhibition of TNF-alpha and wortmannin mediated caspase expression. We hypothesize that this may protect human erythroleukemia cells from apoptosis. The suppressive effect of pilocarpine was further demonstrated by the decreased expression of caspase 3 , which acted as an essential executor and expression of caspase 8 , a biomarker of apoptosis in mammalian cells, which initiated 
receptor-mediated apoptosis. Our findings may partly explain the mechanisms underlying the protective effect of $M_{3}$ muscarinic receptors in apoptosis. The involvement of $\mathrm{M}_{3}$-muscarinic receptors in the protection of cell death induced by TNF-alpha and wortmannin was supported by the up-regulation of PI3K pathway.

In summary, pilocarpine via $M_{3}$ muscarinic receptor appeared to have an inhibitory function and could be regarded as an important mediator in TNF-alpha and wortmannin mediated erythroleukemia cell apoptosis.

Compliance with ethical standards: Ethical approval is not needed (Cell line culture). K562 cells were purchased from the American Type Culture Collection (ATCC) (Rockville, MD).

Conflict of Interest: The authors declare that there is no conflict of interest regarding the publication of this manuscript.

Acknowledgments: This study was supported by a grant from Marmara University Research Fund SAG-CYLP-080.415.0101. We thank Deniz Cabadak for drawing the flowchart for Figure 4.

\section{References}

1. Tong Y, Liu YY, You LS, et al. Perifosine induces protective autophagy and upregulation of ATG5 in human chronic myelogenous leukemia cells in vitro. Acta Pharmacol Sin 2012; 33: 542-50. doi.org/ 10.1038/aps.2011.192

2. Lozzio CB,Lozzio BB. Human chronic myelogenous leukemia cell line with positive Philadelphia chromosome. Blood 1975; 45: 321-34. doi.org/10.1182/ blood-2016-08-736025

3. Bonner TI, Buckley NJ, Young AC, et al. Identification of a family of muscarinic acetylcholine receptor genes. Science 1987; 237:527-32. doi.org/10.1126/science .3037705

4. Kawashima K, Fujii T. Basic and clinical aspects of non-neuronal acetylcholine: Overview of non-neuronal cholinergic systems and their biological significance. J Pharmacol Sci 2008; 106: 167-73. doi.org/ 10.1254/jphs. FM0070073

5. Felder CC. Muscarinic acetylcholine receptors: Signal transduction through multiple effectors. FASEB J 1995; 9:619-25. doi: 10.1096/fasebj.9.8.7768353.

6. Guizzetti M, Costa LG. Activation of phosphatidylinositol 3kinase by muscarinic receptors in astrocytoma cells. Neuroreport 2001; 12: 1639-42. doi: 10.1097/00001.756.200106130-00025

7. Cabadak H, Kücükibrahimoğlu E, Aydin B, ark. Muscarinic receptor-mediated nitric oxide release in a K562 erythroleukaemia cell line. Auton Autacoid Pharmacol 2009; 29: 109-15. doi.org/ 10.1111/j.I474-8673.2009.0043.x
8. Cabadak H, Aydin B, Kan B. Regulation of M2, M3, and M4 muscarinic receptor expression in K562 chronic myelogenous leukemic cells by carbachol. J Recept Signal Transd Res 2011; 31:26-32. doi.org/ 10.3109/10799.893.2010.506484

9. Aydın B, Kan B, Cabadak H. The role of intracellular pathways in the proliferation of human K562 cells that is mediated by muscarinic receptors. Leukemia Res 2013; 37:1144-9. doi.org/10.1016/j.leukres.2013.05.018

10. Fadeel B, Orrenius S. Apoptosis: a basic biological phenomenon with wide-ranging implications in human disease. J Intern Med 2005; 258:479-517. doi.org/10.1111/j. 1365-2796.2005.01570.x

11. Igney FH, Krammer PH. Death and anti-death: tumor resistance to apoptosis. Nat Rev Cancer 2002; 2:277-88. doi. org/10.1038/nrc776

12. Baud V,Karin M. Signal transduction by tumor necrosis factor and its relatives. Trends Cell Biol 2001; 9:372-7. doi. org/ 10.1016/S0962-8924(01)02064-5

13. Boatright KM, Salvesen GS. Mechanisms of caspase activation. Curr Opin Cell Biol 2003; 15:725-31. doi. org/10.1016/j.ceb.2003.10.009

14. Ware CF, VanArsdale S, VanArsdale TL. Apoptosis mediated by the TNF-alpha related cytokine and receptor families. J Cell Biol 1996; 60:47-55. doi.org/10.1002 10.1002/(SICI)1097-4644(19960101)60:1\%3C47::AIDJCB8\%3E3.0.CO;2-3

15. Lowry $\mathrm{OH}$, Rosebrough $\mathrm{NJ}$, Farr AL, et al. Protein measurement with the Folin phenol reagent. J Biol Chem 1951;193:265-75.

16. Eliot R. Spindel. Muscarinic receptor agonists and antagonists: Effects on Cancer. Handb Exp Pharmacol 2012; 208: 451-468. doi.org/ 10.1007/978-3-642-23274-9-19

17. Goeddel DV, Aggarwal BB, Gray PW, et al. Tumor necrosis factors: gene structure and biological activities. Cold Spring Harb Symp Quant Biol 51, 1986: 597-609. doi.org/ 10.1101/ SQB.1986.051.01.072

18. Gonzalez-Flores D, Rodrignez AB, Pariente JA. TNFalpha-induced apoptosis in human myeloid cell lines HL60 and K562 is dependent of intracellular ROS generation. Mol Cellular Biochem 2014; 390:281-7. doi.org/ 10.1007/ s11010.014.1979-5

19. Xuan P, Storr SJ, Zhang Y, et al. Caspase-3 and caspase-8 expression in breast cancer: caspase-3 is associated with survival. Apoptosis 2017; 22: 357-68. doi.org/ 10.1016/ S0898-6568(02)00025-6

20. Corda S, Laplace C, Vicaut E, et al. Rapid reactive oxygen species production by mitochondria in endothelial cells exposed to tumor necrosis factor-alpha is mediated by ceramide. Am J Respir Cell Mol Biol 2001; 24: 762-8. doi. Org/ 10.1080/15384.047.2015.1029835

21. Sandra F, Matsuki NA, Takeuchi H, et al. TNF inhibited the apoptosis by activation of Akt serine/threonine kinase in the human head and neck squamous cell carcinoma. Cell Signal 2002; 14:771-8. doi.org/10.1016/ S0898-6568(02)00025-6

22. Olsen BB, Bjørling-Poulsen M, Guerra B. Emodin negatively affects the phosphoinositide 3-kinase/AKT signalling pathway: a study on its mechanism of action. Int J Biochem 
Cell Biol 2007; 39:227-37. doi:10.1016/j.biocel.2006.08. 006

23. Rudelius M, Pittaluga S, Nishizuka S, et al. Constitutive activation of Akt contributes to the pathogenesis and survival of mantle cell lymphoma. Blood 2006; 108:1668-1676. doi:10.1182/blood-2006-04-015586

24. Wu Q, Chen Y, Cui G, Cheng Y. Wortmannin inhibits K562 leukemic cells by regulating PI3k/Akt channel in vitro. J
Huazhong Univ Sci Technolog Med Sci. 2009; 29:451-6. doi: 10.1007/s11596.009.0412-X

25. Zhao Q, Gu X, Zhang C, et al. Blocking M2 muscarinic receptor signaling inhibits tumor growth and reverses epithelial-mesenchymal transition (EMT) in non-small cell lung cancer (NSCLC). Cancer Biol Ther 2015; 16:634-43. doi:10.1080/153840 47.2015.102.9835 